\title{
Quantification and characterization of hydrological drought in the Oued El-Abid watershed between 1978-2019: Statistical and GIS approaches
}

\author{
Elhoucein Layati ${ }^{1 *}$, Abdelghani Qadem ${ }^{1}$, and Mohamed El Ghachi ${ }^{1}$ \\ ${ }^{1}$ LDRH Laboratory, Sultan Moulay Slimane University, B.P: 524, Beni Mellal, Morocco
}

\begin{abstract}
Hydrological drought is considered an environmental phenomenon related to climate changes that affect natural resources in general. The evaluation of droughts is essential to in the management of water resources. This study aims to demonstrate the use of statistical indices (SSFI and NHI) and GIS (remote sensing) to quantify, characterize and identify hydrologic drought. These indices are applied to the watershed of Oued El-Abid using the annual stream flows time series at the three stations studied (Ait Ouchen, Tilouguit, and Tizi N'Isli), spanning from 1978 to 2019. Results showed that dry and very dry years occur more frequently. Because of, the lake of Bin El-Ouidane dam ismarked by a substantial regression of the water storage. Thematic maps of land use using spatial remote sensing (supervised classification) show that the years 1984, 2000, and 2017 are the driest and most vulnerable years.
\end{abstract}

\section{Introduction}

Climate variability and changes often manifest themselves with the appearance of drought periods, which influence the water resource, the environment and socio-economic activities [1-2]. Several authors have pointed out that it is very difficult to agree on a precise definition of the notion of drought [3-4]. The international glossary of hydrology defined the word drought as a prolonged absence or marked precipitation deficit. According to the National Institute of Agricultural Research [5], drought is a water deficit compared to average or median conditions. This deficit may affect the atmosphere, the soil, surface runoff, and subsurface water, in a given geographical area. There are several types of droughts: meteorological drought, hydrological drought, agronomic drought, and edaphic drought [6-7]: Meteorological droughts are caused by a deficit of precipitation compared to the normal (median or average) for a given period and region [8-9]; Hydrological droughts is related to the decrease of surface runoff in rivers, which leads to low water levels in rivers, lakes or reservoirs and groundwater. [7-10-11-12], Agricultural droughts are related to the other types of droughts (meteorological and hydrological) has an impact on vegetation development. They can be caused deficits in precipitation, an increase in evapotranspiration or the lack of water in soils and water storages [13]. They are highly dependent on climatic conditions, biological and phrenological characteristics of crops and physical and biological properties of soils. Finally, socio-economic droughts as controlled by the relationship between the supply and demand of certain economic goods and some of the elements of meteorological, hydrological, and agricultural droughts (For example: The *Corresponding author:houssa8layati@gmail.com 
supply of many economic goods, such as water, fodder, food grains, fish and hydroelectric power, depends on weather conditions) [14].

This study aims to study, identify and characterize hydrological drought in the Oued El-Abid watershed. The approach adopted is based on the use of statistical indices (SSFI and NHI) on streamflow time series at three hydrometric stations in this watershed: (Ait Ouchen, Tizi N'Isli and Tilouguit). Supervised classification is used to quantify flooded areas during the study period.

\section{Materials and methods}

\subsection{Study area}

Upstream of the Bin El-Ouidane dam, the study area of the present study is part of the Oued El-Abid watershed. It is located in the southeast of the action area of the Oum Er-Rbia Watershed Agency and covers an area of $6405 \mathrm{~km}^{2}$ (Fig. 1). Geographically, this basin is part of the province of Azilal. It is bounded by the province of Beni Mellal, the province of Fkih Beni Saleh in the North, by the province of Ouarzazat in the South, in the East by the provinces of Errachidia and Ouarzaztin the east and the west by the provinces of El Hauz and El Kalaa des Sraghna in the West. On the hydrological plan: The Oued El-Abid has its sources in the jbel Masker ( $3277 \mathrm{~m}$ ) and flows from E to W. The basin has an elongated shape, extends in the heart of the limestone High Atlas, bounded to the E and S by a line of high ridges above $3000 \mathrm{~m}$. The highest point of the basin is the jbel Azourki (3 $690 \mathrm{~m}$ ) [15]. The main tributary of Oued El-Abid is Oued Ahansal. The large storage dam of Binel-Ouidane (storage of 1.5 billion cubic meters) is located shortly after the confluence of these two Oued(Fig. 1). This dam plays an essential role and meets various uses (hydroelectric production, tourist activities, irrigation of the Tadla plain and Tassaout Aval...).

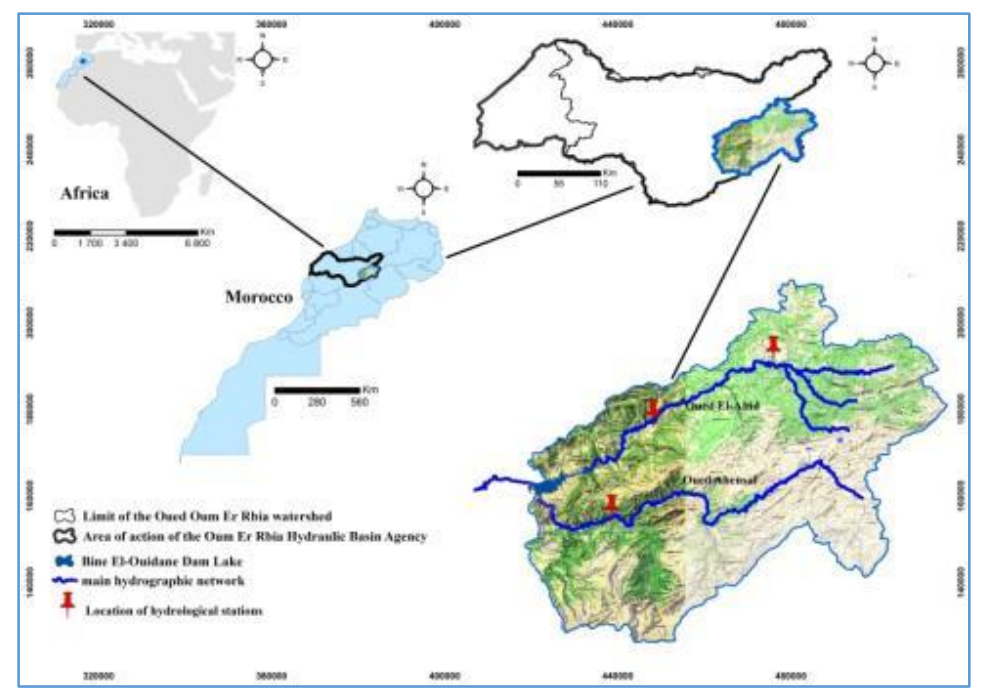

Fig.1. Geographical location of the study area. 


\subsection{Data and Methods}

\subsubsection{Available data}

a. Hydrological data

The Oum Er-Rbia Water Basin Agency provided the hydrometric data used in this study. The data was collected at three hydrometric stations along the Oued (Tab. 1 and Fig. 1).

Table 1.Hydrometric stations.

\begin{tabular}{|l|c|c|c|c|}
\hline Stations & \multicolumn{3}{|c|}{ Lambert coordinates } & \multirow{2}{*}{ Chronicle } \\
\hline Tilouguit & $\mathbf{X}(\mathbf{m})$ & $\mathbf{Y}(\mathbf{m})$ & $\mathbf{Z}(\mathbf{m})$ & \\
\hline & 422670 & 158500 & 1100 & $1978-2019$ \\
Ait Ouchen & 434147 & 185125 & 939 & $1976-2019$ \\
\hline Tizi N'Isli & 432300 & 139600 & 1350 & $1976-2019$ \\
\hline
\end{tabular}

b. Satellite data

Landsat TM images from the years (1984, 1985, 1990, 1992, 1993, 1995, 1998, 1999, 2000, 2001, 2002, 2005, and 2007) were used to perform a diachronic study of basin component change (especially flooded aras), from the Thematic Mapper (TM) sensor and Landsat 8 Operational Land Imager (OLI)from the years (2016 and 2017) images downloaded for free from the website: http://earthexplorer.usgs.gov.

\subsubsection{Characterization of hydrological drought}

Several indices and methods are used to characterize and identify hydrological drought:

- Standardized Streamflow Index (SSFI):

The normalized streamflow index is similar to SPI and was introduced by McKeeet al.1993 [16]. SSFI is the difference between the cumulative flow in a year and the mean and divided by the standard deviation of the series equation (1). The value of SSFI can be used to declare different drought management thresholds (Tab. 2).

With: $F_{i}$ : Flow rate in time interval $\mathrm{i}$;

$$
\mathrm{SSFI}=\frac{F i-\bar{F}}{\sigma}(1)
$$

$\bar{F}$ is meanflow rate of the series;

$\sigma$ is the standard deviation of the series.

- Normalized Hydrologic Index (NHI) :

The Normalized Hydrological Index (NHI) is similar to the Standardized Precipitation Index (SPI); it was developed to quantify the hydrological deficit on several time scales and to show the impact of drought on water resources for a given period [17]. It is expressed mathematically as follows equation (2):

$$
\boldsymbol{N H I}=\frac{\left(\mathrm{D}_{\mathbf{i}}-\mathrm{Dm}\right)}{\mathrm{S}}
$$

With: Di: Discharge of month or year i; Dm: Mean discharge of the series over the considered time scale and S: Standard deviation of the series over the considered time scale. A classification of the drought is made according to the values of the NHI (Tab. 3). 
Table 2. Classification of drought sequences according to SSFI. [18]

\begin{tabular}{|c|c|}
\hline SSFI Values & $\begin{array}{c}\text { Degree of moisture or } \\
\text { dryness }\end{array}$ \\
\hline$\geq 2,0$ & Extreme humidity \\
\hline $1.5-2.0$ & High humidity \\
\hline $1.0-1.5$ & Moderate humidity \\
\hline $0-1.0$ & Light humidity \\
\hline 0 & Light drought \\
\hline$-1.0-0$ & Moderate drought \\
\hline$-1.5--1.0$ & Strong drought \\
\hline$-2.0--1.5$ & Extreme drought \\
\hline$\leq-2.0$ & \\
\hline
\end{tabular}

Table 3. Classification of drought sequences according to NHI. [19]

\begin{tabular}{|c|c|}
\hline NHI values & Drought sequence \\
\hline $0.00<\mathrm{NHI}<-0.99$ & Slightly dry \\
\hline$-1.00<\mathrm{NHI}<-1.49$ & Moderately dry \\
\hline$-1.50<\mathrm{NHI}<-1.99$ & Severely dry \\
\hline $\mathrm{NHI}<-2.00$ & Extremely dry \\
\hline $0.00<\mathrm{NHI}<0.99$ & Slightly humid \\
\hline $1.00<\mathrm{NHI}<1.49$ & Moderately humid \\
\hline $1.50<\mathrm{NHI}<1.99$ & Severely humid \\
\hline $2.00<\mathrm{NHI}$ & Extremely humid \\
\hline
\end{tabular}

\subsubsection{Supervised classification:}

To extract the years of hydrological drought, we start by downloading the satellite images and proceed with the corrections of distorsions that are due to the sensor and atmospheric effects, as shown in (Fig. 2). Secondly, these images were processed and classified based on auxiliary data (terrain data, topographic maps) to obtain land cover maps. On the other hand, the Maximum Likelihood classification was used to map the different components of the study area. Finally, the results were analyzed to extract statistics of the evolution of water surfaces in the watershed from 1978 to 2019, thus determining the most vulnerable years [20]. Finally, we calculate the areas using the numerical count of each class that is equal to the number of pixels that present it. 
The following diagram shows the steps taken to develop maps of the dynamics of the main components in the study area (water surface, vegetation, bare soil, and urbanization).

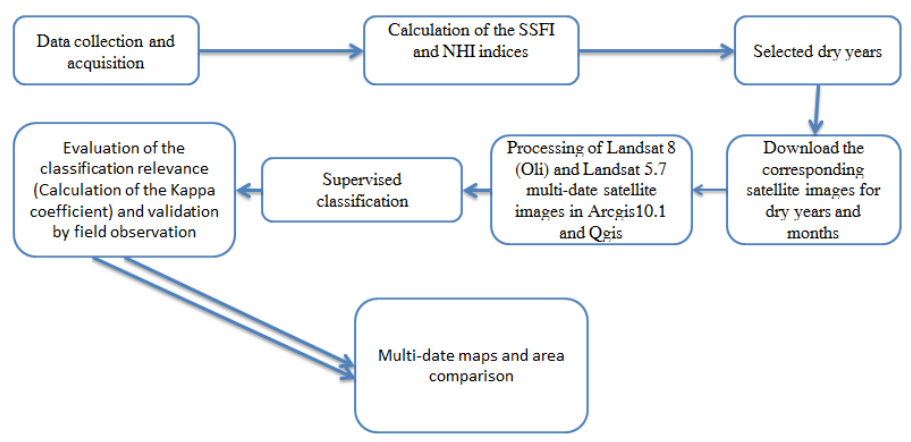

Fig.2. Flow chart of the methodology used to show the driest years.

\section{Results and discussion}

\subsection{Calculation of hydrological drought indices}

- Standardized Streamflow Index (SSFI):

The analysis of the hydrological drought was made by the Standardized Stream Flow Index (SSFI) on a series of observations from 1978 to 2019; the succession between dry and wet years was noticed. The results observed for the three stations have an average frequency of occurrence of $57.5 \%$ for dry years. It is about $50 \%$, of which $55 \%$ and $67.5 \%$ are respectively at the Ait Ouchen, Tilouguit and Tizi N'Isli stations (Tab. 4). The dry years that are common to the three stations are: 1980-1981-1982-1983-1984-1985-1990-19921993-1995-1998-1999-2000-2001-2002-2005-2007-2016 and 2017. The wettest years correspond to the following years: 1996-2009 and 2010 (Fig. 3).

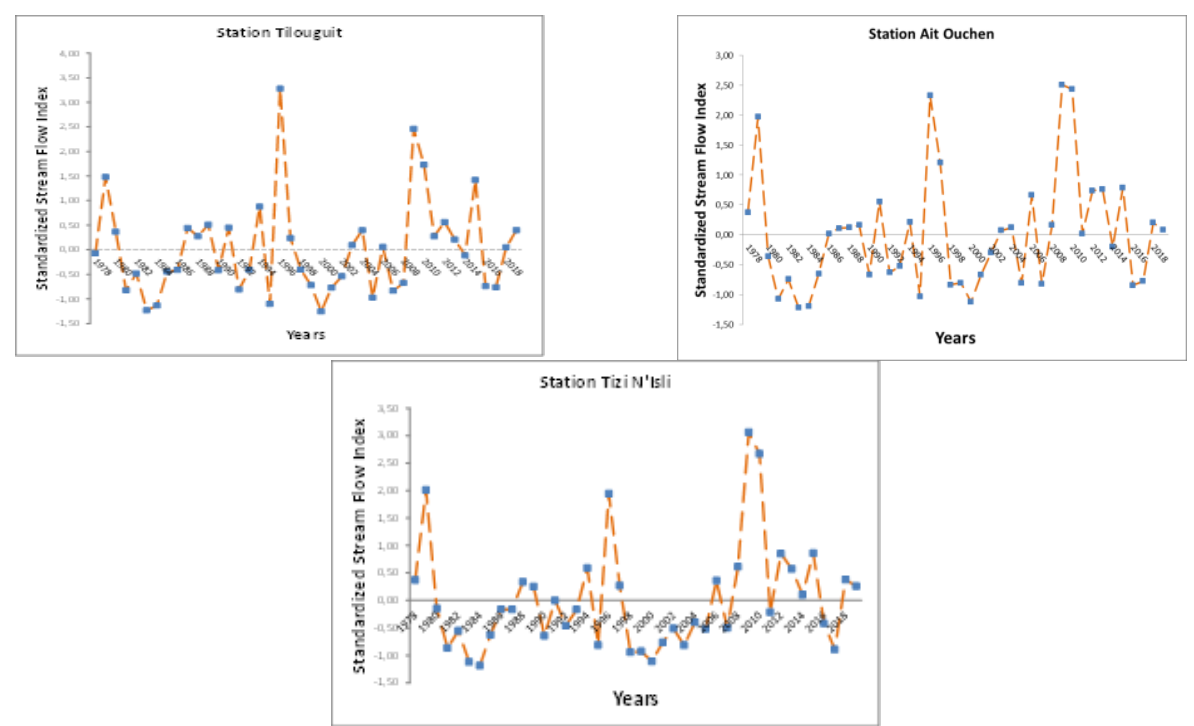

Fig.3. Variation in the Standard Stream Flow Index (SSFI) at the three hydrometric stations. 
Table 4. Frequencies (in \%) of Standard Stream Slow Index (SSFI) for the period 1978-2019 in the Oued El-Abid watershed.

\begin{tabular}{|c|c|c|c|c|c|c|c|c|c|c|}
\hline & \multicolumn{4}{|c|}{ Wet period } & & \multicolumn{4}{|c|}{ Dry period } & \multirow[b]{2}{*}{$\begin{array}{c}\text { Tota } \\
\text { in } \\
(\%)\end{array}$} \\
\hline & $\begin{array}{l}\text { Extreme } \\
\text { humidity } \\
(\geq 2.0)\end{array}$ & $\begin{array}{l}\text { High } \\
\text { humidity } \\
(1.5 \text { to } \\
2)\end{array}$ & $\begin{array}{c}\text { Moderate } \\
\text { humidity } \\
(1.0 \text { to } \\
1.5)\end{array}$ & $\begin{array}{c}\text { Light } \\
\text { humidity } \\
(0 \text { to } \\
1.0)\end{array}$ & $\begin{array}{c}\text { Normal } \\
(0)\end{array}$ & \begin{tabular}{|c|} 
Light \\
drought \\
$(0$ to - \\
$1)$ \\
\end{tabular} & $\begin{array}{c}\text { Moderate } \\
\text { drought } \\
(-1 \text { to - } \\
1.5)\end{array}$ & $\begin{array}{c}\text { Severe } \\
\text { drought }(<- \\
1.5 \text { to }-2.0)\end{array}$ & $\begin{array}{c}\text { Extreme } \\
\text { drought }(\leq \\
-2.0)\end{array}$ & \\
\hline \begin{tabular}{|l|} 
Ait \\
Ouchen \\
\end{tabular} & 7.5 & 2.5 & 2.5 & 37.5 & \multirow[b]{2}{*}{ 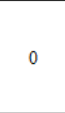 } & 37.5 & 12.5 & 0 & 0 & \multirow[b]{2}{*}{100} \\
\hline \begin{tabular}{|l|} 
Total \\
frequency \\
in (\%) \\
\end{tabular} & \multicolumn{4}{|c|}{50} & & \multicolumn{4}{|c|}{50} & \\
\hline \begin{tabular}{|l} 
Tilouguit \\
\end{tabular} & 5 & 2.5 & 5 & 32.5 & & 45 & 10 & 0 & 0 & \multirow[b]{2}{*}{100} \\
\hline \begin{tabular}{|l|} 
Total \\
frequency \\
in (\%)
\end{tabular} & \multicolumn{4}{|c|}{45} & 0 & \multicolumn{4}{|c|}{55} & \\
\hline \begin{tabular}{|l|} 
TiziN'Isli \\
\end{tabular} & 0 & 2.5 & 0 & 27.5 & & 52.5 & 7.5 & 0 & 7.5 & \\
\hline \begin{tabular}{|l|} 
Total \\
frequency \\
in (\%)
\end{tabular} & \multicolumn{4}{|c|}{30} & 2.5 & \multicolumn{4}{|c|}{67.5} & 100 \\
\hline
\end{tabular}

- Normalized Hydrologic Index (NHI) :

The results obtained by the Normalized Hydrological Index are presented in Tab. 5 and Fig. 4. The three hydrometric stations showed an alternation of surplus and deficit years (figure below).
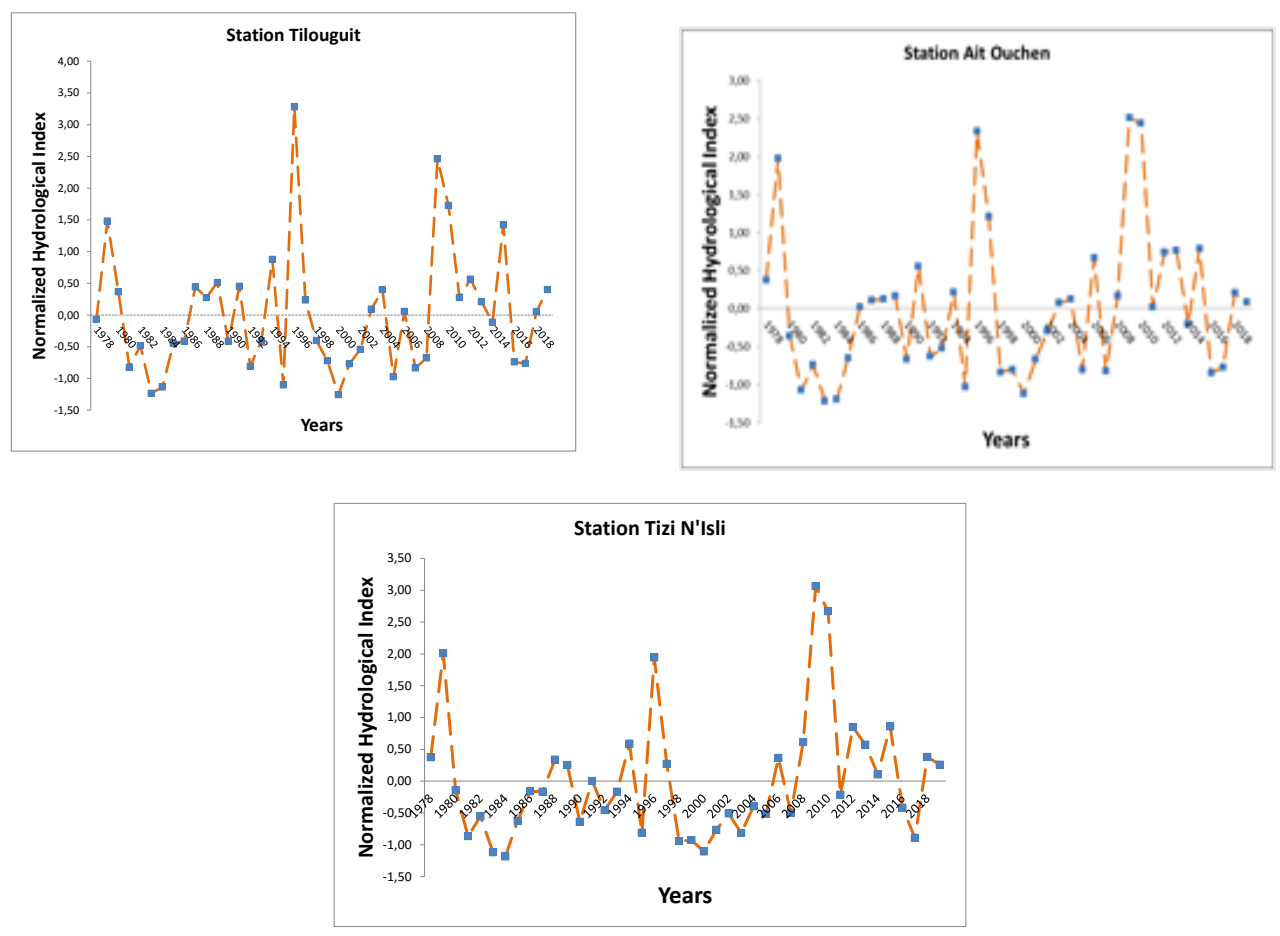

Fig.4. Variation of the Normalized Hydrological Index in the three hydrometric stations. 
Table 5. The flow regime's frequency of dry and wet periods in the three stations studied in the Oued El-Abid watershed (1978 to 2019).

\begin{tabular}{|c|c|c|c|c|c|c|c|c|c|}
\hline & \multicolumn{4}{|c|}{ Wet period } & \multicolumn{4}{|c|}{ Dry period } & \multirow[b]{2}{*}{$\begin{array}{c}\text { Total } \\
\text { in } \\
(\%)\end{array}$} \\
\hline & $\begin{array}{c}\text { Extreme } \\
\text { humidit } \\
\mathrm{y} \\
(2.00<\mathrm{N} \\
\mathrm{HI})\end{array}$ & $\begin{array}{c}\text { Severe } \\
\text { humidit } \\
\mathrm{y} \\
(1.50< \\
\mathrm{NHI}<1 . \\
99)\end{array}$ & $\begin{array}{c}\text { Moderate } \\
\text { humidity } \\
(1.00< \\
\text { NHI }<1.4 \\
9)\end{array}$ & $\begin{array}{c}\text { Light } \\
\text { humidity } \\
(0.00<\mathrm{N} \\
\mathrm{HI}<0.99)\end{array}$ & $\begin{array}{c}\text { Light } \\
\text { drought } \\
(0.00< \\
\mathrm{NHI}<- \\
0.99)\end{array}$ & $\begin{array}{c}\text { Moderate } \\
\text { drought (- } \\
1.00< \\
\text { NHI }<-1.49)\end{array}$ & $\begin{array}{c}\text { Severe } \\
\text { drought(- } \\
1.50<\mathrm{NHI} \\
<-1.99)\end{array}$ & $\begin{array}{c}\text { Extreme } \\
\text { drought } \\
(\mathrm{NHI}<- \\
2.00)\end{array}$ & \\
\hline Ait Ouchen & 7.5 & 2.5 & 7.5 & 37.5 & 37.5 & 7.5 & 0 & 0 & \\
\hline $\begin{array}{l}\text { Total } \\
\text { frequency } \\
\text { in }(\%)\end{array}$ & \multicolumn{4}{|c|}{55} & \multicolumn{4}{|c|}{45} & 100 \\
\hline Tilouguit & 5 & 2.5 & 5 & 32.5 & 45 & 10 & 0 & 0 & \\
\hline $\begin{array}{l}\text { Total } \\
\text { frequency } \\
\text { in }(\%)\end{array}$ & \multicolumn{4}{|c|}{45} & \multicolumn{4}{|c|}{55} & 100 \\
\hline Tizi N'Isli & 7.5 & 2.5 & 0 & 30 & 52.5 & 7.5 & 0 & 0 & \\
\hline $\begin{array}{l}\text { Total } \\
\text { frequency } \\
\text { in (\%) }\end{array}$ & \multicolumn{4}{|c|}{40} & \multicolumn{4}{|c|}{60} & 100 \\
\hline
\end{tabular}

The average frequency of deficit periods is $54 \%$ the three stations. The average frequency is of wet periods is $47 \%$ (table above). The years of drought common to all the stations are: 1981-1982-1983-1984-1985-1990-1993-1998-1999-2000-2001-2002-20052007-2016-2017. The wettest years are 1996-2009 and 2010, which had very high precipitation amounts.

\subsection{Supervised classification}

The total precision values calculated for our study area are shown in Tab 6. Knowing that the critical value for the acceptance of this classification is $75 \%$ [21-22]. Therefore, we can conclude that there is an excellent correspondence between the mapping obtained from the classification of remote sensing data and the field observations.

Table 6. Summary table of classification accuracy.

\begin{tabular}{|l|c|c|c|c|c|c|c|c|c|c|c|c|c|c|c|}
\hline $\begin{array}{l}\text { Selected } \\
\text { dyy years }\end{array}$ & 1984 & 1985 & 1990 & 1992 & 1993 & 1995 & 1998 & 1999 & 2000 & 2001 & 2002 & 2005 & 2007 & 2016 & 2017 \\
\hline $\begin{array}{l}\text { Total } \\
\text { precision } \\
\text { values }\end{array}$ & 100 & 98.48 & 100 & 96.52 & 99.55 & 98.48 & 100 & 98.99 & 98.20 & 99.15 & 98.70 & 99.13 & 99.70 & 99.50 & 99.70 \\
\hline
\end{tabular}

The various treatments on the selected images allowed us to generate land use maps from a supervised classification of multiple components of the area studied. The results obtained show that the driest and most vulnerable years are: 1984, 2000, and 2017 when water body surface are as were respectively about 3903.5 ha (Figure 6a), 4156.6 ha (Figure 6i) and 3850.3 ha (Figure 6o). As it is shown [20]. This decline is due mainly to climatic conditions characterized by the regression of rainfall contributions and increase in the needs of the population in different uses: production of electrical energy (industrial and domestic consumption), irrigation (agriculture), drinking water supply, and water recreation (tourism) [23]. Precisely, the hydrological drought infects the filling of the dam lake Bin El-Ouidane. This confirms the results obtained by Qadem et al. [20]. According to which, over the last three decades, the dam has experienced very significant variations in its water height and impoundment, the general trend of which tends to recede with a decrease of almost $40 \%$ (Fig. 5) thanks to the occurrence of drought episodes [20-24]. 


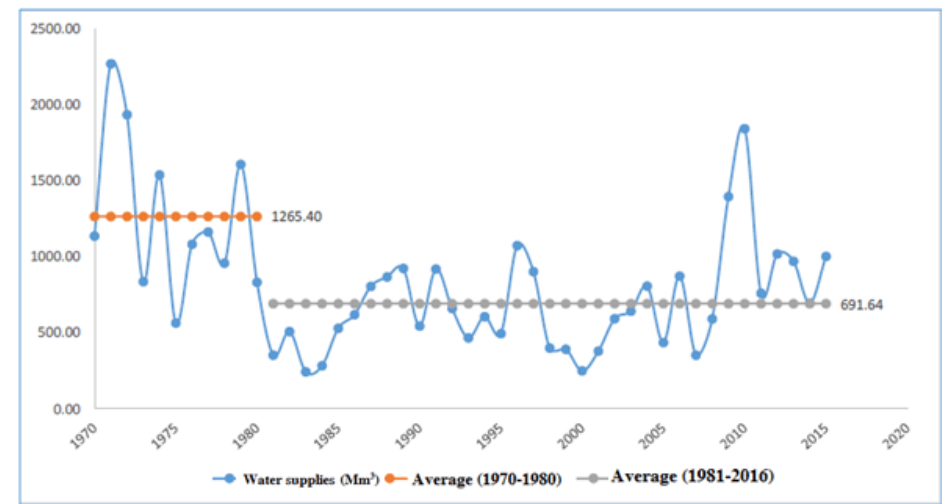

Fig.5. Annual water supply of the Bin El-Ouidane dam.

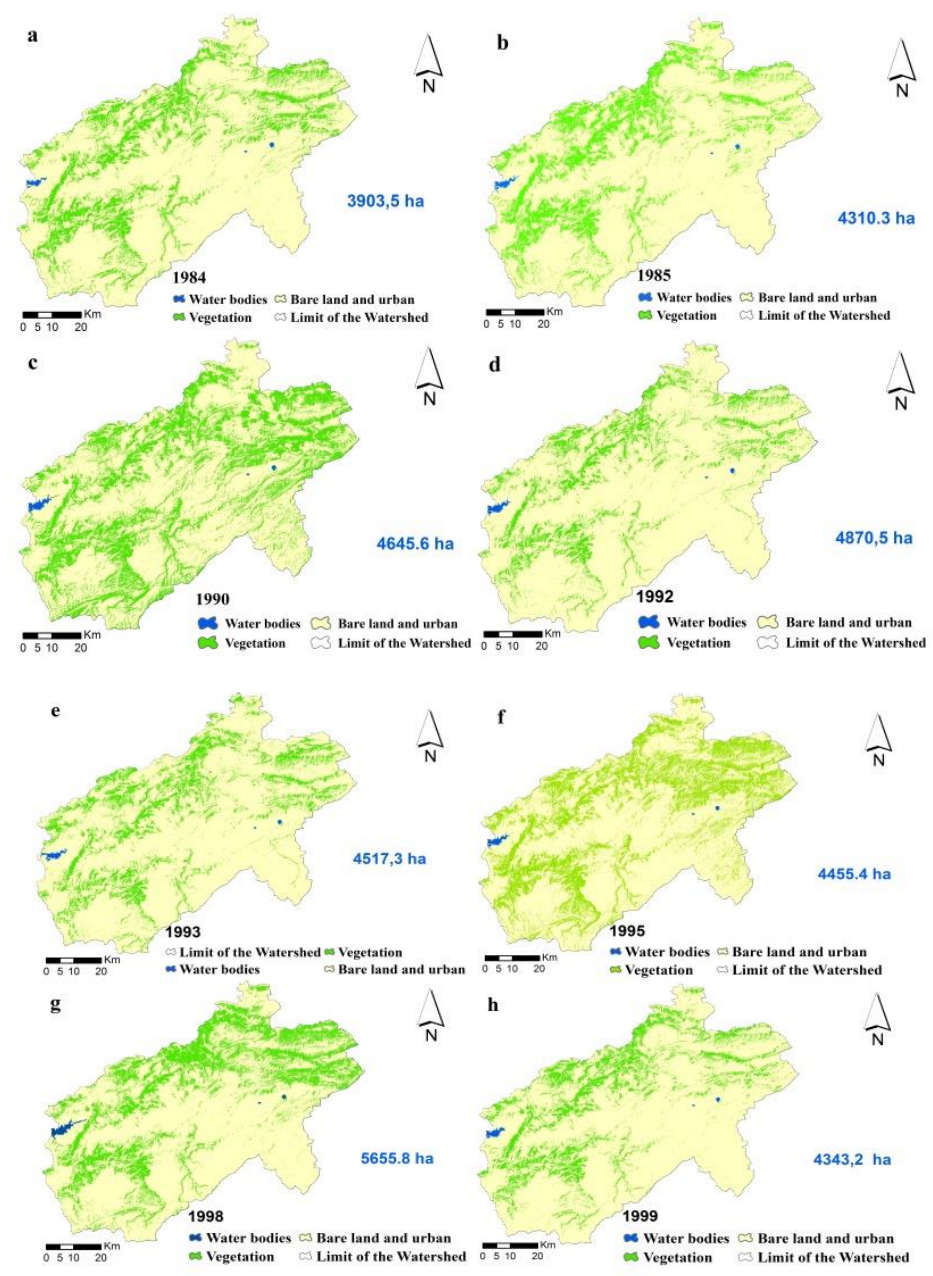




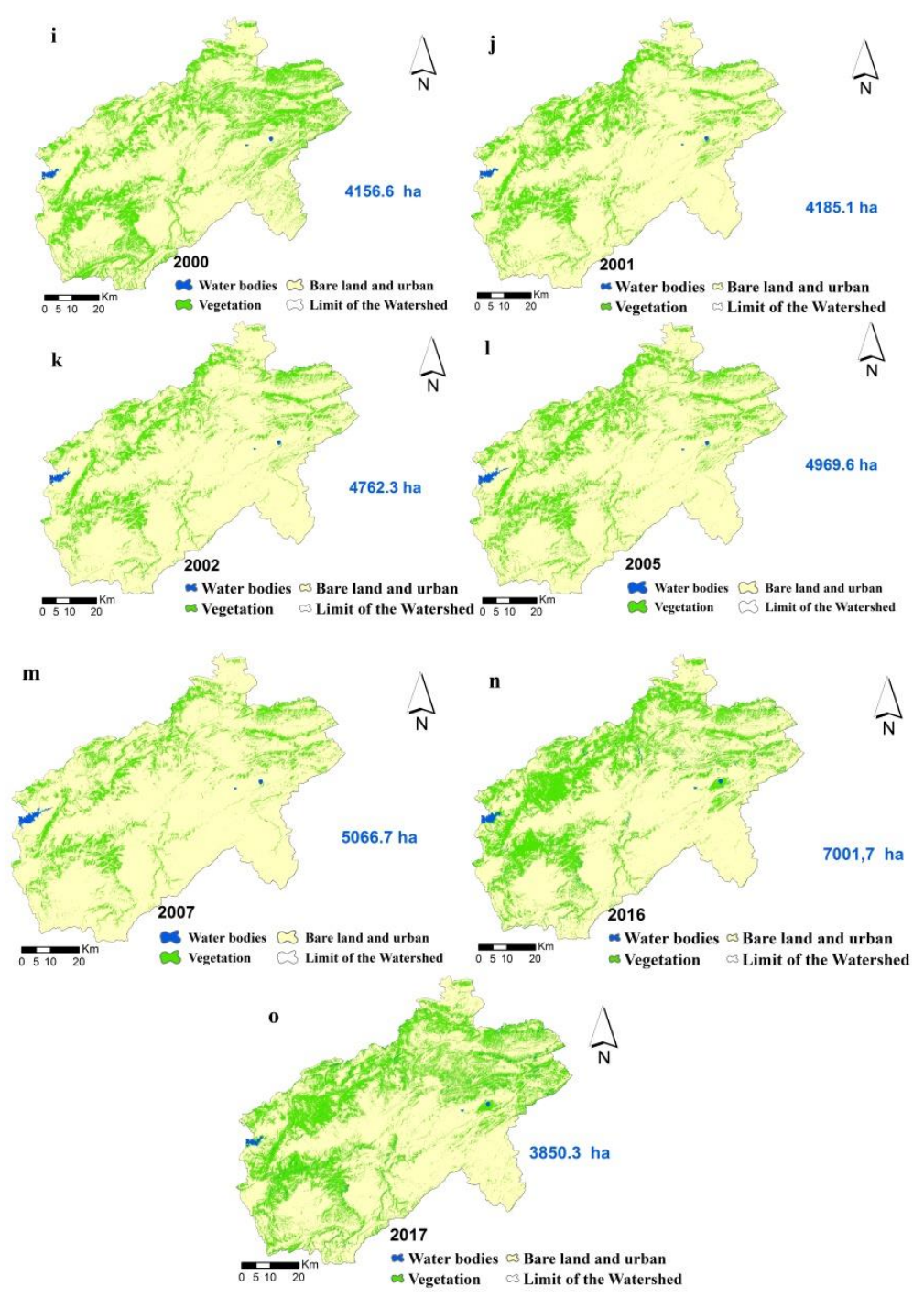

Fig.6. Detection of water body changes in the watershed between 1978 and 2019.

\section{Conclusions}

In this study, hydrological drought in the watershed of Oued El-Abid during the period 1978-2019was analyzed using two indices SSFI and NHI. Results showed that the study area experienced dry years during 18 years from 1981 to 1985 , the hydrological years of 1990-192-1993-1995, 1998 to 2002 and 2005-2007-2016-2017. Spatial remote sensing applied to on Landsat images allowed to make a diachronic study of land use during the periods of drought, and to show the most vulnerable years. It was found that three years (1984, 2000 and 2017) are the driest years in the study period. The changes are due to the annual and interannual variability of flows resulting from rainfall variability. 


\section{Acknowledgment}

The authors wish to thank the hydraulic basin agency of Oum Er-Rabia for providing data used in this paper.

\section{References}

1. S. M. Vicente-Serrano, S. Beguería, L. Gimeno, L. Eklundh, G. Giuliani, D. Weston, A. El Kenawy, J.I. López-Moreno, R. Nieto, T. Ayenew, D. Konte, J. Ardö, G. G. S,Pegram. AppliedGeography, 34, 471-486 (2012)

2. D.D. BA, Sécheresse climatique, dynamique actuelle et perspectives des activités agropastorales dans le Ferlo et la Moyenne Vallée du fleuve Sénégal (Région de Matam), Section de géographie, Sénégal, Thèse de doctorat unique, Université Gaston Berger de Saint -Louis, 196 p (2019)

3. A.Khaldi, Impacts de la sécheresse sur le régime des écoulements souterrains dans les massifs calcaires de l'Ouest Algérien " Monts de Tlemcen - Saida", thèse doctorale, Université D’Oran, pp: 13-18 (2005)

4. D. El Hafid, Z. Zerrouqi, B. Akdim. Larhyss Journal, 31, pp. 83-94 (2017)

5. J.P. Amigues, P. Debaeke, B. Itier, G. Lemaire, B. Seguin, F. Tardieu, A. Thomas, Sécheresse et agriculture. Réduire la vulnérabilité de l'agriculture à un risque accru de manque d'eau. Expertise scientifique collective, Rapport, INRA, France, p. 10 (2006)

6. M. Svoboda, D. Lecomte, M. Hayes, R. Heim, K. Gleason, J. Angel, B. Rippey, R. Tinker, M. Palecki, D. Stooksbury, D. Miskus, S. Stephens, The Drought Monitor,Bulletin of the American Meteorological Society 83(8), pp. 1181-1190 (2002)

7. J. Spinoni, G. Naumann, H. Carrao, P. Barbosa, J. Vogt, Int. J. Climatol. 34, pp.2792-2804 (2014)

8. E.A.B. Eltahir, P.J.F.Yeh, On the asymmetric response of aquifer water level to floods and droughts in Illinois, Water Resour. Res. 35 (4), pp.1199-1217 (1999)

9. R.R. Heim,Bulletin of the American Meteorological Society 83, PP. 1149-1165 (2002)

10. Z. Sen. J. Hydraulics Div., ASCE 106 (1), pp. 99-115 (1980)

11. D.M. Frick, D. Bode, J.D. Salas,J. Hydrological Eng. 116, PP. 733-753 (1990)

12. B. Boudad, H. Sahbi , I. Manssouri,J. Mater. Environ. Sci, 9(1) (2018)

13. D.A. Wilhite, M.H. Glantz, Water Int. 10( 3), pp.111-120(1985)

14. American Meteorological Society (AMS). Soc. 85, pp. 771-773 (2004)

15. M. ElGhachi, H. Ouakhir H. Lameti, Revue Marocaine de Géomorphologie, $\mathrm{N}^{\circ} 3$, pp 63-45 (2019)

16. T.B. McKee, N.J. Doesken, J. Kleist.American Meteorological Society, Jan 1723, Anaheim CA, pp. 179-186 (1993)

17. T.C. Sharma, U.S. Panu. Hydrological Sciences Journal, 55 (1), pp. 79-92. (2010).

18. A.Ghenim, LJEE $\mathrm{N}^{\circ} 18$ (2011)

19. Bi. V. H .N'Gnessan, M. B .Saley, M.O. Yeï, A.F. Yapi, B.H.Kouadio, J. Biemi, A. Kouadio,Int J Engineering Science. Vol X Issue X \| XXXX: 1-11 (2017) 
20. A.Qadem, M. El Ghachi, E. Layati,Geomaghreb 15, pp. $41-47$ (2019)

21. M. Girard, Télédétection appliqué, zone tempérées et intertropicales, Rapport, Paris, 260p (1999)

22. E. Layati, A. Ouigmane,M.D.C Alves, M. Bagyaraj, A. Qadem, M. El Ghachi.Papers in AppliedGeography, DOI:10.1080/23754931.2021.1973545 (2021)

23. H. Ouakhir, M. El Ghachi, in Renforcement de la résilience des hydrosystèmes face aux changements globaux: "de la mesure hydrologiqueaux modèles de gestion” (Béni Mellal - Maroc), CES'2015, 143p (2018)

24. GIEC, Changements climatiques 2014: Rapport de synthèse. Contribution des Groupes de travail I, II et III au cinquième Rapport d'évaluation du Groupe d'experts intergouvernemental sur l'évolution du climat [Sous la direction de l'équipe de rédaction principale, R.K. Pachauri et L.A. Meyer]. GIEC, Genève, Suisse, 161p (2014) 